\title{
Rozumienie pojęć moralnych w wychowaniu moralnym dzieci młodszych. Empatia i motywacja do zachowań moralnych
}

\section{THE UNDERSTANDING OF MORAL TERMS IN MORAL EDUCATION OF YOUNGER CHILDREN. EMPATHY AND MOTIVATION FOR MORAL BEHAVIOURS}

The problem of understanding terms has been the subject of numerous analyses and investigations, whereas understanding moral terms by children of younger school age has not been the subject of analyses or research studies. This made me undertake research on morality, understanding it and creating terms. Bearing in mind Albert Schweitzer's formulation that all good actions are born of hope, I based the concept of experimental stage adaptations of literary texts on the comparison of intelligence and child's personality. Studying mutual relations between intelligence and personality is still a topical issue. In my view, creating and understanding moral terms in the process of teaching, thinking and discussing them takes place mainly in Polish studies. I did not separate moral terms from thinking, the sphere of feelings and free will in this education process.

Mother tongue classes, literary texts should open man to the world, pointing out unquestionable moral values, which are the basis of our existence, our human existence. The truth, good, beauty are ageless values in every sphere of humanity. Hope is hidden in cognition and understanding their contents. The truth exists for every man, only when man himself as a complex person creates the truth in acting. 
Key words: values, norms, assessments and moral terms, empathy and motivation for moral behaviours.

Problematyka rozumienia pojęć była przedmiotem licznych analiz i dociekań naukowych, natomiast rozumienie pojęć moralnych przez dzieci w młodszym wieku szkolnym nie stanowiło ani analiz ani opracowań badawczych. Ta okoliczność skłoniła mnie do podjęcia badań nad moralnością, jej rozumieniem i kształtowaniem pojęć. Pozostając przy sformułowaniu Alberta Schweitzera, że wszelkie dobre działanie ma swoje źródło w nadziei, oparłam koncepcję eksperymentalnych inscenizacji teatralnych tekstów literackich na zbliżeniu inteligencji i osobowości dziecka. Poszukiwanie wzajemnych relacji między inteligencją i osobowością stanowi problem wciąż aktualny. Kształtowanie rozumienia pojęć moralnych w procesie nauczania, myślenia i rozważania o nich, moim zdaniem odbywa się przede wszystkim na edukacji polonistycznej. Nie oddzielałam w tym procesie kształtowania pojęć moralnych od myślenia, strefy uczuć i woli.

Lekcje języka ojczystego, teksty literackie powinny otwierać człowieka na świat, wskazując na niezaprzeczalne wartości moralne, które są podstawą naszego istnienia, naszej ludzkiej egzystencji. Prawda, dobro, piękno to wartości ponadczasowe, aktualne w każdym wymiarze humanistyki. Ich poznanie, zrozumienie treści kryją w sobie nadzieję. Prawda bowiem istnieje dla każdego człowieka, tylko wtedy kiedy on sam, jako złożona osoba tworzy ją w działaniu.

„W owej chwili wielkie pytanie, przed którym stanie ludzkość, nie będzie brzmiało: Jak żyłem? Będzie brzmieć: Jak kochałem? Ostateczną próbą w drodze do zbawienia jest miłość. Bez znaczenia będzie to, co zrobiliśmy, w co wierzyliśmy, w co wierzyliśmy, czego dokonaliśmy"1.

\section{Wartości etyczne - zagadnienia ogólne}

Rozważania etyczne nad zjawiskami i pojęciami moralnymi sięgają Arystotelesa (384-322 r. p.n.e.) - twórcy terminu ,etyka”. Etyka zajmuje się rozważaniem dobra i zła. Sugeruje jakie motywy powinny kierować

1 P. Coelho, Być jak ptynaca rzeka, Warszawa 2013, s. 77. 
postępowaniem człowieka. Słusznie twierdzi Maria Ossowska, że zadaniem etyka jest ocenianie ludzkich zachowań. Współczesna etyka oferuje człowiekowi konkretną pomoc, z kolei socjologia moralności bada jej społeczne przejawy. Zaś psychologia moralności stawia przed sobą zadanie poznania świadomości moralnej człowieka². Badania semantyczne nad językiem moralnym dopełniają wiedzę o moralności. One to dostarczają danych, w oparciu o które lepiej można zrozumieć istotę pojęć moralnych.

$\mathrm{Z}$ dostępnych ludzkiemu poznaniu zjawisk, które nazwano moralnymi (łac.: mos, moris - zwyczaj, obyczaj), nauka o moralności wyróżnia wiele pojęć moralnych, m.in. takie jak: koleżeńskość, obowiązkowość, współczucie, miłość, wdzięczność, szacunek, przywiązanie, odwaga, uczciwość, odpowiedzialność.

Dlatego istotnym jest, jak sądzę, rozumienie wartości etycznych, bo ono ułatwia poznanie praw moralnych i ich przestrzeganie.

Moje rozważania w tym artykule traktuję o rozumieniu przez filozofię, pedagogikę i psychologię wartości, norm, ocen i pojęć moralnych. Świat wartości etycznych dziecka jest czasem „stworzenia człowieka”. Inaczej mówiąc: dziecko jest człowiekiem in statu nascendi, które przyjmuje lub odrzuca poznanie praw idealnych, czyli powszechnych.

\section{Wartości, normy, oceny i pojęcia moralne}

Arystoteles sądził, że człowiek ma równe dyspozycje do realizowania w praktyce różnych cnót moralnych, choć mogą one konkurować ze sobą. Starożytni filozofowie uznawali konkurencję cnót moralnych, a szczególną uwagę przypisywali osiągnięciu równowagi w całym życiu istoty ludzkiej jako obronę własnej tożsamości i własnego systemu wartości ${ }^{3}$. Sąd ten stanowi -jak myślę - przekonanie o decydującej roli człowieka jako twórcy własnego życia i podmiotu przekształcającego rzeczywistość.

Ta ogólna teza budowania wartościowej etycznie osobowości człowieka łączy rozważania teoretyków myśli filozoficznej ze współczesnymi tendencjami psychologii humanistycznej reprezentowanej przez A. H. Maslowa, C. R. Rogersa, D. H. Heath'a. W ostatnich latach coraz częściej podejmuje się próby stworzenia systemu wychowania humanistycznego, którego celem byłoby ukształtowanie osoby w pełni dojrzałej, która umiałaby aktualizować swoje potencjalne szanse rozwoju.

2 J. Pawlica, Podstawowe pojęcia etyki, Wrocław 1978, s. 27-28.

3 J. Kozielecki, O godności człowieka, Warszawa 1977, s. 22. 
Na ten temat Józef Kozielecki sądzi, iż „wychowanie humanistyczne" należy uznać za ciągle niezrealizowany projekt, bowiem brak jest konkurencyjnych rozwiązań pedagogicznych, pomimo tego, iż psychologowie humanistyczni odkryli nowe obszary badawcze, sformułowali oryginalne pytania, które dotychczas były pomijane, pokazali „,sprawy ludzkie" niedostrzegane przez uczonych ${ }^{4}$.

Wartości moralne nadają człowiekowi poczucie godności osobistej. moralna Proces ten przejawia się głównie w formie słownej, która wymaga od ucznia pewnego stopnia rozwoju aparatu poznawczego - zdolności do symbolicznego ujmowania doświadczeń. Moralność określa możliwie korzystne zachowanie się ludzi.

Dla filozofii przełomowe znaczenie miała książka G. E. Moore’a pt. Principia ethica. Praca ta promuje zupełnie nowe rozumienie dobra - jako wartości. Co najmniej równie doniosłe znaczenie, jak rozważania G. E. Moore'a posiada analiza wartości dokonana kilkanaście lat później przez Maxa Schelera. Analizując świat wartości Max Scheler filozof, etyk odkrywa w nim szereg obiektywnych, a zarazem koniecznie obowiązujących praw. Wartości dzielą się na pozytywne i negatywne, przy czym nie możliwe jest, by jedna i ta sama wartość była raz pozytywna, a kiedy indziej negatywna. Każda wartość zawiera w swej istocie pewien moment decydujący o jej „wyższości” lub „niższości”. Do tych momentów należą: trwałość, niepodzielność, możliwość warunkowania innej wartości, zdolność wywoływania określonego zadowolenia. Moralne postępowanie człowieka zależy przede wszystkim od tego , jakie wartości on realizuje, a jakie odrzuca. Człowiek staje się dobrym, gdy urzeczywistnia w sobie wartości pozytywne, a w każdym razie stara się urzeczywistniać je złym - gdy dopuszcza realizację wartości negatywnych. Rozum i emocje decydują o ich wyborze. Uczucia zdaniem Maxa Schelera, nie są wyłącznie stanem podmiotu, lecz w swych rozmaitych odmianach mają szczególną wartość poznawczą.

Kierunki współczesnej filozofii zakładają częściową i całkowitą poznawalność wartości, której przedstawicielami są m.in. N. Hartmann, M. Ossowska, B. Russell, M. Scheler, F. Znaniecki. Problematyka filozofii wartości pojawia się również w pracach $\mathrm{R}$. Ingardena, który to wyróżnia trzy rodzaje wartości: witalne, kulturalne i moralne ${ }^{5}$. Człowiek jako twórca wartości realizuje je nie tylko w sobie, ale i poza sobą. Sądy o wartościach są typowe dla ogólnej teorii i filozofii wartości - aksjologii wartości. W rozważaniach o wartości, koniecznym wydaje się uwzględnienie myśli etycznej A. Schweitzera, stanowiącej

$4 \quad$ J. Kozielecki, Koncepcje psychologiczne człowieka, Warszawa 1976, s. 267, 272.

R. Ingarden, Przė̇ycie - dzieło - wartość, Kraków 1966. 
ważny składnik tworzonej przez niego w latach 20. XX wieku filozofii kultury, koncentrującej się na poszukiwaniu uniwersalnej zasady etycznej. Znajduję ją właściwie w filozofii A. Schweitzera, w formie „szacunku do życia”.

Wśród filozofów - etyków dostrzec można różne punkty widzenia dobra i zła. I tak fenomenologowie (F. Brentano, M. Scheler, Wł. Tatarkiewicz) twierdzili, że coś jest uważane za słuszne, ponieważ odpowiada dobru obiektywnemu.

Z kolei metaetyka badając znaczenie terminów etycznych podejmuje analizy logiczne oraz interesuje się zagadnieniami psychologicznymi. Schweitzer wyraża zdanie, że każdy moralista winien przedstawić swoje przemyślenia odnośnie naczelnej wartości w jednej zasadzie, lub w jednej cnocie podstawowej. Tę podstawową cnotę zamknął Albert Schweitzer w haśle „czci dla życia” - Ehrfurcht vor dem Leben ${ }^{7}$. Podobnie Wł. Tatarkiewicz podjął i rozwinął tę ideę naczelnych wartości w pracy Dzieje sześciu pojęć - „... były i są odróżniane trzy najwyższe wartości: dobro, piękno, prawda"8. Tę myśl polskiego filozofa przyjmuję jako zasadniczą dla dalszych rozważań o normach, ocenach i pojęciach moralnych.

\section{Rola rozumienia pojęć w wychowaniu moralnym - kształtowanie kompetencji społecznych dziecka}

Badacze i historycy myśli pedagogicznej podkreślają fakt, że poezja, literatura, sztuka przepojone są głęboką myślą wychowawczą. Zatem wszelka twórczość odnosząca się do ludzkiej egzystencji, ludzkiego losu, jego szczęścia i jego dramatu jest przejawem postaw wychowawczych. Przykładem wartości duchowych mogą być: dobroć, przyjaźń, miłosierdzie, współczucie, tolerancja, wdzięczność, miłość, szacunek. Należy zauważyć, że teorie J. Piageta i L. Kohlberga uzupełniają teorie filozoficzne, etyczne, pedagogiczne.

W koncepcjach obu psychologów, badaczy rozwoju moralnego poszukiwałam uzasadnienia wykorzystania wartości tekstów literackich do budowania systemu wartości. Wartości literatury pięknej łagodzą wszak przejawy osamotnienia, smutku, bezradności i niepokoju. Rozważałam tu myśl L. Wygotskiego, traktującą o sferze najbliższego rozwoju, określanej jako różnica między tym, co dziecko potrafi samo a tym, co może zrobić przy pomocy.

\footnotetext{
$6 \quad$ A. Schweitzer, Życie, Warszawa 1974, s. 63.

7 Ibidem.

8 W. Tatarkiewicz, Dzieje sześciu pojęć, Warszawa 1976, s. 9.
} 
Psychologia poznawcza zajmuje się rozwojem zdolności dziecka do rozumowania moralnego. Teoretycy tego kierunku twierdzą, że etapy rozwoju poznawczego stanowią podstawy rozwoju moralnego. Aby wyjaśnić postępowanie moralne dziecka musimy najpierw poznać jego zdolności rozumowania oraz jego wiedzę o problemach moralnych. W koncepcjach psychologicznych twierdzi się także, że postępowanie moralne dziecka powinno charakteryzować się znaczną stałością w różnych sytuacjach i odzwierciedlać jednolity proces, w którym rozumowania moralne są ściśle połączone z teoriami rozwoju poznawczego, traktują one zazwyczaj rozwój moralny jako przechodzenie poprzez szereg odrębnych stadiów.

Model rozwoju moralnego Piageta wyrósł z wczesnych prac badacza prowadzonych w Genewie w Szwajcarii w latach 20. i 30. XX wieku. Piaget uważał, że rozumowanie moralne, podobnie jak rozwój poznawczy jest sterowane zarówno przez czynnik wrodzony, jak i środowiskowy. Uzależnione od natury zaawansowania poznawczych zdolności dzieci, w tym odejście od myślenia egocentrycznego, umożliwia im gromadzenie większej ilości informacji i przyjmowanie przy ocenie moralnej sytuacji kilku punktów widzenia. Dalej Piaget uważa, że doświadczenia społeczne odgrywają ważną rolę w przechodzeniu dziecka z jednego stadium do drugiego. We wczesnych latach życia dzieci uczą się, że to zazwyczaj rodzice narzucają im reguły postępowania i domagają się ich przestrzegania. Lecz jednokierunkowa natura tego systemu nie pozwala dzieciom na wyrażanie własnego punktu widzenia i uświadamiania sobie, że w kwestiach moralnych mogą istnieć różne opinie. $\mathrm{W}$ tym momencie kontakty z rówieśnikami stają się ważnym czynnikiem socjalizacyjnym.

Drugą znaczącą koncepcję rozwoju moralnego zaproponował Lawrence Kohlberg, psycholog z Uniwersytetu w Harwardzie. Model Kohlberga pojawił się w 1958 roku w rozprawie doktorskiej, w której autor podjął próbę sprawdzenia teorii Piageta za pomocą nowych metod badawczych. Kohlberg badał 72 chłopców w wieku 10-16 lat. Metoda Kohlberga, polegała na prezentowaniu dylematów moralnych w celu oszacowania ich poziomu rozwoju moralnego. Przy każdym takim dylemacie prosił osobę badaną o wskazanie, co bohater historyjki powinien zrobić i dlaczego. W modelu Kohlberga to drugie pytanie jest ważniejsze, ponieważ przypuszczalnie ujawnia poziom myślenia osoby badanej o sytuacji problemowej. Na podstawie wyników tych badań wywnioskował, że rozwój rozumienia moralnego przebiega przez trzy poziomy. Na każdym poziomie są dwa stadia. W swoich późniejszych pracach Kohlberg twierdził, że w obecnej chwili stadium 6 jest bardziej 
teorią niż rzeczywistością. Niewiele jednostek osiąga to stadium i nie ujawniło się ono u żadnej z osób badanych kiedykolwiek przez niego. Mimo to Kohlberg przypuszcza, że może także istnieć stadium 7 rozwoju moralnego, przekraczające konwencjonalne rozumowanie moralne i wkraczające w sferę wiary religijnej ${ }^{9}$.

Ważnym aspektem modelu Kohlberga jest określenie, jak przebiega interakcja między dwoma komponentami danego stadium. Na przykład dziecko znajdujące się w stadium 1 jest egocentryczne i spostrzeTeologia ga wszystkie sytuacje $\mathrm{z}$ własnego punktu widzenia. W toku rozwoju staje się coraz zdolne do oceny dylematu z perspektywy innych i do określenia, co jest lepsze dla społeczności jako całości. Postępy w tym zakresie są związane z poznawczym rozwojem jednostki. Jednak coraz lepsze przyjmowanie perspektywy innych nie wystarcza do osiągnięcia postępów w rozumowaniu moralnym. Musi temu towarzyszyć rozwój komponentów w treści moralnej, co do którego zakłada się, że silnie uzależniony od doświadczeń dziecka z sytuacjami moralnymi. Teoria Kohlberga przypomina teorię Piageta w tym, że rozwój moralny stanowi rezultat połączenia doskonalących się zdolności poznawczych i powtarzających się kontaktów z problemami moralnymi.

Przechodzenie do kolejnych stadiów w modelu Kohlberga ściśle odpowiada Piagetowskiemu procesowi akomodacji. Przejście takie następuje, kiedy dziecko nie może dłużej dopasować nowej informacji do własnej wizji świata, w terminologii Piageta - kiedy nie może dłużej asymilować nowych informacji do posiadanych schematów poznawczych. W propozycji Kohlberga przypisuje się szczególne znaczenie sposobności ,podejmowania ról”, która ma miejsce, gdy dzieci uczestniczą wraz z innymi w sytuacjach podejmowania decyzji i wymiany poglądów na kwestie moralne. Przeciwstawne punkty widzenia wywołują konflikt poznawczy, który dziecko w końcu rozwiązuje poprzez przeorganizowanie swojego myślenia w bardziej zaawansowane stadium rozumowania. Ten proces postępuje stopniowo i jeśli nawet rozumowanie danej osoby zostanie zakwalifikowane do jednego ze stadiów, to może ona podejmować do niektórych kwestii moralnych tak, jakby była w stadium wyższym lub niższym.

Nie bez znaczenia dla wyborów założeń eksperymentu była refleksja na temat możliwości pogodzenia pedagogiki serca i pedagogiki rozumu. W przestrzeni wyborów w improwizacjach teatralnych, dramie jest miejsce na publiczne wyrażanie marzeń cichych i osobistych. Ale ta droga do marzeń, którą zaproponowałam w moim eksperymencie

$9 \quad$ L. Kohlberg, Rozwój jako cel wychowania, [w:] Z. Kwieciński, L. Witkowski (red.), Spory o edukacje, Warszawa 1993. 
nie jest tylko drogą zabawy. Realizacja marzeń wymaga wielkiego wysiłku, radości życia, aktywności i pokonywania przeszkód. Marzeniem dziecka jest zaistnienie wśród innych, odniesienie sukcesu, bycie zauważonym. Dla rodziców i pedagogów sprawą najwyższej wagi jest rozwój moralny dziecka, jego etyczne postępowanie, przyjęcie wartości duchowych i rozumienie ich.

W moich badaniach naukowych poddałam analizie aspekt poznawczy pojęć moralnych, a nie zachowanie dzieci. Uczyniłam to z pewną świadomością, bowiem decyzje i zachowania moralne podejmowane są jako rezultat procesów poznawczych, moralnej wiedzy, przekonań lub rozumienia moralnego ${ }^{10}$.

W dobie załamania wielu wartości i przekonań etycznych postawiłam sobie za cel pracy kształtowanie rozumienia pojęć moralnych. Łamanie norm moralnych, jakże częste krzywdy wyrządzane dzieciom przez dorosłych, dorosłym przez dzieci są wezwaniem dla pedagogów i psychologów do podjęcia w problematyce badawczej i refleksji naukowej tej zawsze aktualnej problematyki. A podjęte zagadnienia wymagały syntezy pedagogiki i psychologii, filozofii i edukacji literackiej.

Wybór dziesięciu pojęć moralnych uważam za słuszny, ponieważ to one są wpisane w treści polonistyczne wprowadzające dziecko w wieku ośmiu, dziewięciu lat w świat rozważań etycznych. Kohlberg, podobnie jak Piaget, uważają, że źródłem tych doświadczeń i stymulatorem rozwoju moralnego są interakcje społeczne. Stworzyłam je jako inscenizacje tekstów literackich na lekcjach edukacji polonistycznej w klasie II i III edukacji wczesnoszkolnej. Wybrane przeze mnie teksty literackie znanych, polskich autorów są nośnikiem wartości moralnych. Mity i baśnie dostarczają wielu wzorów postępowania oraz wskazują na autorytety moralne. Dzieło moralne jest więc tworem wielowartościowym. Dobroć w prozie dla dzieci powiązana jest z odwagą, męstwem i współodczuwaniem. Taka postawa bohaterów służy wyeksponowaniu wzoru osobowego, w którym ponadto odnajdujemy inne wartości etyczne: odpowiedzialność, prawość, wierność, a także wspaniałomyślność, uprzejmość, roztropność. Można też stwierdzić jednoznacznie, że celem działań takiego bohatera jest „dobro” i „,pożytek" oraz to, co moralnie piękne. Wymienione wcześniej wartości są przekazywane w utworach jako idee.

Przede wszystkim szczególne zadanie przypisują współcześni badacze literatury dziecięcej tradycyjnej baśni. To baśń tłumaczy radość i smutek spełnionych lub niespełnionych marzeń. Baśnie mogą mieć

10 J. Piaget, Rozwój ocen moralnych dziecka, Warszawa 1967, s. 90-101, 290, 293, 313-344. 
ogromny wpływ na moralny rozwój dziecka, nigdzie bowiem tak dobitnie nie jest postawiony problem dobra i złą. Dobroć, pracowitość, odwaga, a obok tego chciwość, skąpstwo, tchórzostwo i lenistwo, przedstawione w dramatycznej akcji wzruszają dziecko do głębi i każą mu stanąć po stronie pozytywnych wartości moralnych, których głębię i autentyzm ukazuje właśnie baśń.

Świadome czytanie z pełnym zrozumieniem pozwala dziecku podejmować różnorodne działania praktyczne, ruchowe i werbalne dostosowane do treści zawartych w lekturze. W edukacji wczesnoszkolnej jednym z tego rodzaju działań są różne formy dramatyzacji tekstu. Proponuję nauczycielom i studentom na zajęciach edukacji polonistycznej zapoznanie się z fenomenem inscenizacji improwizowanych. Inscenizacje improwizowane, czy też gry dramatyczne (jeux dramatiques) to forma interesującego teatru dziecięcego. Odwołuje się ona do spontanicznej ekspresji właściwej dla wielu uczniów edukacji wczesnoszkolnej. Jako pierwszy zastosował gry dramatyczne w latach 30. XX wieku, francuski autor i pedagog Leon Chancerel. Później nad tą formą pracowali P. Slade i B. Way. Les jeux dramatiques to nowa forma pracy z dzieckiem nawiązująca do zabaw i gier, jako naturalnej i twórczej jego aktywności. W improwizacji dramowej występują co najmniej trzy płaszczyzny, dzięki którym może nastąpić zmiana w pojmowaniu rzeczywistości. Jest to płaszczyzna wynikająca z kontekstu, płaszczyzna uniwersalna oraz osobista.

Proponowane przeze mnie improwizacje tekstów literackich przez dzieci są przedstawieniem bez scenariusza. W związku z tym, że scenariusz jest niepotrzebny wydarzenie nie zależy od wprawy lub zdolności w czytaniu czy też od uczenia się i zapamiętania roli. Dzięki temu jest on aktywnością, którą posiadają wszystkie dzieci, we wszystkich grupach wiekowych.

Jest to rzeczywiście bardzo potrzebna aktywność w doświadczaniu problemów dziecięcych, ale bardzo też ważnych społecznie i kulturowo. Uczniowie w trakcie zabawy w teatr uczą się rozumienia takich pojęć jak: koleżeństwo, obowiązkowość, współczucie, miłość, wdzięczność, szacunek, przywiązanie, odwaga, uczciwość, odpowiedzialność.

A przecież to właśnie dziecko jest wrażliwe na prawdę, sprawiedliwość, piękno. Dziecko pragnie w prawdzie odnaleźć siebie, dlatego szuka, często burzliwie prawdziwych wartości i ceni tych ludzi, którzy ich nauczają i przede wszystkim według nich żyją.

$\mathrm{Z}$ tą głęboką refleksją pozostawiam moich Czytelników, którym dane będzie prowadzić swoich uczniów drogą wielkich wartości 
humanistycznych. Ja takich nauczycieli znałam. Dobry i mądry nauczyciel winien otwierać dzieci na dobro.

Edukacja polonistyczna sprzyja kształtowaniu postaw, które uczą tego, jak być szczęśliwym. Wierzę, że mądry człowiek, mądry, rozważny nauczyciel znajdzie drogę do swoich uczniów, wypełni ich świat wartościami ponadczasowymi.

Słowa kluczowe: wartości, normy, oceny i pojęcia moralne, empatia i motywacja do zachowań moralnych.

\section{Bibliografia:}

1. Ajdukiewicz K., Logika pragmatyczna, Warszawa 1975.

2. Cieślikowski J., Literatura dziecięca. Teoria i krytyka literatury dla dzieci i młodzieży, Warszawa 1985.

3. Cieślikowski J., Literatura i podkultura dziecięca, Wrocław 1975

4. Cieślikowski J., Wielka zabawa, Wrocław 1967

5. Coelho P., Być jak ptynaca rzeka, Warszawa 2013.

6. Folkierska A., Typy wartości, ich miejsce i funkcjonowanie w kulturze [w:] H. Świda (red.) Młodzież a wychowanie, Warszawa 1979.

7. Freinet C., L'éducation morale et civique, Canne 1961.

8. Gołąb A., Doświadczenie jako kategoria psychologii rozwoju, [w:] A. Gurycka (red.), Przedmiotowość $w$ doświadczeniach dzieci i młodzieży, Warszawa 1989.

9. Gołąb A., Normy moralne a gotowość udzielania pomocy innym, [w:] J. Reykowski (red.), Osobowość a społeczne zachowania się ludzi, Warszawa 1976.

10. Gołąb A., Przejawy rozwoju moralnego jednostki, [w:] H. Jankowski (red.), Etyka, Warszawa 1973.

11. Grzybek G., Etyka rozwoju a pedagogika opiekuńcza, Rzeszów 2013.

12. Grzybek G., Etyka rozwoju a wychowanie, Rzeszów 2010.

13. Guzowski J., Etyczny wymiar wychowania, Olsztyn 2011.

14. Hazard P., Ksiażki - dzieci i dorośli, Warszawa 1963.

15. Ingarden R., Przeżycie - dzieto - wartość, Kraków 1966.

16. Kohlberg L., Die Psychologie der Moralentwicklung, Frankfurt1995.

17. Kohlberg L., Candee D., The relationship of moral judgment to moral action [w:] W. M. Kurtines, J. Gewirtz (red.), Morality, moral behavior and moral development, Wiley, New York 1984.

18. Kohlberg L., Moral Development [w:] International Encyclopedia of the Social Sciences, t. 10, New York 1968.

19. Kohlberg L., Moral education in the schools a developmental view, „School Review" t. $74 \mathrm{nr} 1$ (1966).

20. Kohlberg L., Rozwój jako cel wychowania [w:] Z. Kwieciński, L. Witkowski (red.), Spory o edukację. Dylematy i kontrowersje we wspótczesnych pedagogiach, Warszawa 1993. 
21. Kohlberg L., The development of children's orientations toward a moral order, „Vita Humana” t. 6 (1963).

22. Kołakowski L., Mini wykłady o maxi sprawach, Kraków 2009.

23. Kotarbiński T., Istota oceny etycznej, „Etyka” nr 1 (1966).

24. Kozielecki J., Koncepcje psychologiczne człowieka, Warszawa 1976.

25. Kozielecki J., O godności człowieka, Warszawa 1977.

26. Kozielecki J., Twórczość i rozwiązywanie, [w:] M. Materska, T. Tyszka (red.), Psychologia i poznanie, Warszawa 1992.

27. Lazari-Pawłowska I., Schweitzer, Warszawa 1976.

28. Mariański J., Kontrowersje wokót relacji religii i moralności tożsamość czy rozbieżność? Studium socjologiczne, Torun 2014.

29. Nalaskowski A., Przeciwko edukacji sentymentalnej, Kraków 1994.

30. Okoń W., Dziesięć szkót alternatywnych, Warszawa 1997.

31. Okoń W., Zabawa a rzeczywistość, Warszawa 1995.

32. Ossowska M., Pojęcie moralności, „Etyka” nr 1 (1966).

33. Ossowska M., Socjologia moralności, Warszawa 1963.

34. Papuzińska J., Leszczyński G., Dzieciństwo i sacrum. Studia i szkice literackie, Warszawa 1998.

35. Pawlica J., Podstawowe pojęcia etyki, Wrocław 1978.

36. Piaget J., Inhelder B., Psychologia dziecka, Wrocław 1996.

37. Piaget J., Narodziny inteligencji dziecka, Warszawa 1966.

38. Piaget J., Psychologia i epistemologia, Warszawa 1977.

39. Piaget J., Rozwój ocen moralnych dziecka, Warszawa 1967.

40. Piaget J., Równoważenie struktur poznawczych, Warszawa 1981.

41. Piaget J., Sad i rozumowanie u dziecka, Lwów - Warszawa1966.

42. Piaget J., Studia z psychologii dziecka, Warszawa 1966.

43. Piotrowski P., Górniewicz J., Pedagogika kultury i postkultury, Olsztyn 2015.

44. Propp W., Nie tylko bajka, Warszawa 2000.

45. Przetacznik-Gierowska M., Tyszkowska M., Psychologia rozwoju człowie$k a$, t. 1, Warszawa 1990.

46. Przetacznikowa M., Podstawy rozwoju psychicznego dzieci i młodzieży, Warszawa 1978.

47. Vasta R., Haith M. M., Miller S. A., Psychologia dziecka, Warszawa 1995.

48. Rynio A. (red.), Religijno-moralny wymiar rozwoju i wychowania, Lublin 2012.

49. Schweitzer A., Die Lehre von der Ehrfurcht vor dem Leben Grundtexte aus fünf Jahrzehnten, München 1966.

50. Schweitzer A., Życie, Warszawa 1974.

51. Starnawski W., Bycie osoba podstawy moralności i wychowania, Warszawa 2011.

52. Śliwerski B., Istota i przedmiot teorii wychowania, [w:] B. Śliwerski, Z. Kwieciński, (red.) Pedagogika. Podręcznik akademicki, t. 2, Warszawa 2008.

53. Śliwerski B., Wspótczesne teorie i nurty wychowania, Kraków 2003.

54. Tatarkiewicz W., Dzieje sześciu pojęć, Warszawa 1976.

55. Tischner J., Myślenie wedtug wartości, Kraków 2005. 
56. Tischner J., Spór o istnienie człowieka, Kraków 2011.

57. Tomasz a Kempis, O naśladowaniu Chrystusa, Warszawa 1980.

58. Trempała J. (red.), Rozwijający się człowiek $w$ zmieniającym się świecie, Bydgoszcz 1995.

59. Trempała J., Rozumowanie moralne i odporność dzieci na pokusy oszustwa, Bydgoszcz 1983.

60. Trzebiński J., Twórczość a struktura pojęć, Warszawa 1981.

Teologia

61. Walczyna J., Ksztattowanie postaw społeczno-moralnych dzieci w wieku przedszkolnym, Warszawa 1978.

62. Walczyna J., O niektórych dylematach wychowania w przedszkolu, „Kwartalnik Pedagogiczny" nr 3 (1981).

63. Wojtyła K., Miłość i odpowiedzialność, Lublin 2010.

64. Wojtyła K., Osoba i czyn oraz inne studia antropologiczne, Lublin 1994.

65. Wygotski L. S., Wybrane prace psychologiczne, Warszawa 1971.

66. Zimbardo P., Psychologia i życie, Warszawa 1999.

67. Żurakowski B., Literatura. Wartość. Dziecko, Kraków 1999. 